\title{
AMELIORATATIVE EFFICACY OF CURCUMIN IN HEALING THE HISTOPATHOLOGICAL LESIONS IN SCHISTOSOMA MANSONI INFECTED MICE
}

By

HADEER A. RASHED ${ }^{1 *}$, NAHLA S. EL-SHENAWY, MAHA F. M. SOLIMAN ${ }^{2}$, and ALI H. ABU ALMAATY ${ }^{1}$

Department of Zoology, Faculty of Science, Port Said University, Port Said ${ }^{1}$ and

Department of Zoology, Faculty of Science, Suez Canal University, Ismailia, $41522^{2}$, Egypt ("Correspondence: hader_abdelhak@hotmail.com).

\begin{abstract}
Schistosoma species is a blood-parasite causing schistosomiasis, a neglected tropical pathological disorder affecting millions of people worldwide. This work studied the efficiency of curcumin in restoring liver and spleen ratios to body weight and enhancing the histological architecture in $S$. mansoni infected mice. Forty CD1 male mice were divided into four groups (10mice/group). G1 (treated with phosphate buffer and act as control), G 2 (treated with curcumin), G3 (infected-untreated), and G4 (infected \& treated with curcumin). After seven weeks of infection, each group was injected for three times/week intraperitoneal. The mice body weights were weekly recorded and they were sacrificed by the end of the $8^{\text {th }}$ week. Liver and spleen were removed immediately and weighted to calculate their ratios to body weight. The histological sections of liver and spleen were prepared to study pathological changes between the different groups. Granuloma number and diameter change rate in liver were done. The result showed that schistosomiasis caused significant retardation in body weights in experimental mice. Curcumin mildly enhanced body weight in certain weeks. Liver ratio to body weight was significantly reduced in infected mice treated with curcumin as compared with infected untreated ones. There was a marked improvement in liver and spleen histopathology in curcumin-treated mice.
\end{abstract}

Keywords: Anti-schistosomal, curcumin, histopathology, liver, spleen, granuloma, organs ratios.

\section{Introduction}

Schistosoma is a blood-dwelling parasitic worm that causing schistosomiasis, a neglected tropical pathological disorder affecting millions of individuals worldwide (WHO, 2018). Schistosomiasis mansoni led to hepatosplenic disease with risky complications (Richter et al, 2015). Intestinal causes many disorders as abdominal pain, diarrhea, and bloody stool, Liver enlargement in advanced cases with an accumulation of fluid in peritoneal cavity and hypertension (WHO, 2019). S. mansoni-infected animals suffered from significant growth retardation and hepatosplenomegaly (Jatsa et al, 2018). Liver enlargement is assigned in the more advanced cases with an accumulation of fluid in the peritoneal cavity and hypertension of the abdominal blood vessels (WHO, 2019). Spleen is affected by schistosomiasis in different degrees concerning the hepatic portal circulation (Wang et al, 2015 ). Egg production by the female $S$. mansoni, which may reaches per day from hundreds to thousands, is the principal stimulant of the chronic lesions, as it causes granuloma formation in different body organs like gut, intestine, liver, spleen, bladder, and even lungs (Araújo et al, 2010; Wang et al, 2015).

Schistosomiasis treatment is still depended on praziquantel (PZQ) as a drug of choice (Hotez et al, 2007). But, its efficiency has been reduced in the infected animals (Crellen et al, 2016). So, it was important to monitor for new drugs under global pressure on PZQ use (Woldegerima et al, 2019).

Curcumin isolated from the rhizome of plant Curcuma longa has a principal active ingredient in tropical and subtropical countries (Černy et al, 2011). Curcumin have different therapeutic biological activities including, anti-inflammatory, antioxidant, antitu- 
mor anticoagulant, and hepatoprotective activities (Anand et al, 2008). Antischistosomal therapeutic effects of $C$. longa extract was proved (Mahmoud and ELbessoumy, 2014; Hussein et al, 2017).

This work aimed to study efficacy of curcumin in healing schistosomiasis in infected mice and its ability in enhancing the liver and spleen ratios as compared to the body weight.

\section{Material and Methods}

Experimental animal and design: Forty white male albino mice with an average weight of $20 \pm 3 \mathrm{~g}$ were obtained from Theodore Bilharz Research Institute (TBRI, Imbaba, Giza, Egypt). The animals were then placed in the animal house of the Zoology Department, Faculty of Science, Port-Said University. They were divided into four groups of 10mice each. G1 was treated with phosphate buffer (solvent of curcumin), G2 was treated with curcumin, at dose of $20 \mathrm{mg} /$ $\mathrm{kg}$ of body weight, G3 was infected but untreated as positive control, and G4 was infected and treated with curcumin as control negative.

All mice were left in the animal house for a week for adaptability. The G1 and G2 are negative animals while, the mice in groups 3 , and 4 were incubated with $60 \pm 10 \mathrm{~S}$. mansoni cercariae for an hour according to a partial immersion technique of Olivier and Stirewatt (1952). Stool samples were collected after 7 weeks post-infection in G3 \& $\mathrm{G} 4$ to check for $S$. mansoni eggs under light microscope to prove positivity. Body weights of mice were recorded weekly from the first week of infection until the $8^{\text {th }}$ experimental week (second week post-treatment).

Powder curcumin (C21H20O6) was purchased from Sigma Aldrich. 1M phosphate buffer $\mathrm{pH} 7$ was used as a solvent of curcumin to make the used proper concentration $(20 \mathrm{mg} / \mathrm{kg}$ body weight). All mice either infected or not were given treatment at the same time. At the $7^{\text {th }}$ week post-infection, mice were injected intraperitoneal (IP) with $20 \mathrm{mg} / \mathrm{kg}$ of body weight for groups 2 , and 4 .
The different injections were applied three days/week for two weeks. The scarification of mice in all groups occurred at the end of the second week of treatment, one day after receiving the last dose of the different regimens.

Organs ratio/indices: Immediately before scarification, each mice was weighed individually and the liver and spleen were removed from the body. The organs were dried on clean filter paper. The liver and the spleen indices were calculated as the ratio of liver and spleen, respectively to each mouse's body weight $(\mathrm{g})$.

Histopathological studies: Immediately after dissection, parts of liver, and spleen were fixed in $10 \%$ buffered formalin, embedded in paraffin, sections of $4 \mu \mathrm{m}$ thickness were stained with hematoxylin, and eosin. Histological changes between the groups were captured using CMEX (10 pros) software.

The mean granuloma diameter and its number were done after Mahmoud and Warren (1974) and Reis et al. (2001), respectively. The mean values reduction rates of granuloma diameter and number in group treated with curcumin were carried out according to the equation $\mathrm{P}=(\mathrm{C}-\mathrm{V}) / \mathrm{C}^{*} 100(\mathrm{P}=$ reduction percentage, $\mathrm{C}=$ averages number or diameter of granulomas in infected-un-treated mice, \& V = averages number or diameter of granulomas in infected-treated mice.

Statistical analysis: Data were subjected to Student's t-test version 20 of the SPSS program to determine the significance of results. A value of $\mathrm{P}<0.05$ was considered significant.

\section{Results}

The averages changes in body weights of different groups were given (Tab. 1). In the normal negative groups G1 \& G2), there were no significant changes among mice all over the experiment. However, there were significant changes in the average of the body weights in the infected untreated animals as compared with the control phosphate buffer mice. The infected-untreated 
mice showed a significant increase in body tion to the $6^{\text {th }}$ week $(29.31 \pm 0.94)$ as compared with the negative control group.

At experimental end, infected-untreated mice showed a significant decrease $(\mathrm{P}<0.03)$ in body weight $(21 \pm 1.22)$. Infected mice treated with curcumin showed significant body weights enhancement in $1^{\text {st }}$ week as compared to infected-untreated ones $(\mathrm{P}<0.03)$.

There were changes in body organ ratios of mice 2 weeks post-treatment (Tab. 2). In the normal negative mice, curcumin didn't affect both liver and spleen ratios to body weight as compared to phosphate buffer group. Infected-untreated mice showed a significant rise in liver $(9.83 \pm 0.28, \mathrm{P}<0.000)$, and spleen $(1.38 \pm 0.09, \mathrm{P}<0.03)$ ratios to body weight as compared with control mice. Curcumin significantly enhanced and reduced liver/body weight $(8.27 \pm 0.13)$ ratio in infected treated mice $(\mathrm{P}<0.01)$ as compared with infected untreated ones.

Microscopically liver in phosphate buffer mice showed normal hepatocytes radiating from central vein (Fig. 1A). Hepatocytes were acidophilic with central pale stained nuclei separated by alternated blood sinusoids forming a network. Sinusoid-associated macrophages, Kupffer cells were seen (Figs. 1A, B). Control mice treated with curcumin weight from $3^{\text {rd }}$ week $(24.63 \pm 0.98)$ of infecshowed slightly dark hepatocytes without changes in the central veins nor blood sinusoids (Figs. 1C, D).

The infected-untreated mice showed some pathological changes in liver tissues. Granulomas were composed of fibrous and inflammatory cellular portions (Fig. 1E), with deformed areas as dilated sinusoids and damaged hepatocytes (Fig. 1F). Portal veins were highly dilated with some cellular infiltration diffusion (Fig. 1G). Infected mice treated with curcumin showed pathological changes enhancement than in untreated mice, especially hepatocytes as the intact cells inc-reased (Fig. 1H, I). Granulomas number was significantly reduced $(\mathrm{P}<0.000)$ as compared with infected untreated mice (Tab. 3).

In normal uninfected groups (Figs. 2A, D), spleen parenchyma architecture was co-mposed mainly of red pulp (lightly stained) and white pulp (highly stained). White pulp with central arteriole was surrounded by immune cells. Pathological lesions in infected-untreated mice were partial disappearance of boundary between white and red pulps, necrotic areas (Fig. 2E, F) and fibrosis in some splenic regions (Fig. 2G). Spleen of infected mice treated with curcumin showed neither fibrosis nor fibrotic areas reduction (Fig. 2H, I).

Table 1: Changes in the average body weights of mice during experimental period $(\mathrm{n}=10)$.

\begin{tabular}{|c|c|c|c|c|c|c|c|c|}
\hline Group & $\begin{array}{c}1^{\text {st }} \\
\text { Week }\end{array}$ & $\begin{array}{c}2^{\text {nd }} \\
\text { Week }\end{array}$ & $\begin{array}{c}3^{\text {rd }} \\
\text { Week }\end{array}$ & $\begin{array}{c}4^{\text {th }} \\
\text { Week }\end{array}$ & $\begin{array}{c}5^{\text {th }} \\
\text { Week }\end{array}$ & $\begin{array}{c}6^{\text {th }} \\
\text { Week }\end{array}$ & $\begin{array}{c}1^{\text {st }} \\
\text { of Treatment }\end{array}$ & $\begin{array}{c}2^{\text {nd }} \\
\text { Treatmeek of }\end{array}$ \\
\hline $\begin{array}{c}\text { Phosphate } \\
\text { buffer }\end{array}$ & $20.83 \pm 0.31$ & $21.17 \pm 0.54$ & $20.67 \pm 0.76$ & $21.33 \pm 0.76$ & $22.50 \pm 0.67$ & $24.0 \pm 0.58$ & $24.50 \pm 0.43$ & $24.33 \pm 0.61$ \\
\hline Curcumin & $21.0 \pm 0.52$ & $20.83 \pm 0.87$ & $21.17 \pm 0.87$ & $22.0 \pm 0.86$ & $23.17 \pm 0.87$ & $23.83 \pm 0.95$ & $24.83 \pm 0.75$ & $25.17 \pm 0.65$ \\
\hline $\begin{array}{c}\text { Infected } \\
\text { untreated }\end{array}$ & $20.75 \pm 0.84$ & $22.38 \pm 0.88$ & $24.63 \pm 0.98^{\mathrm{a}}$ & $27.25 \pm 1.16^{\mathrm{a}}$ & $27.25 \pm 1.05^{\mathrm{a}}$ & $29.31 \pm 0.94^{\mathrm{a}}$ & $23.50 \pm 1.09$ & $21 \pm 1.22^{\mathrm{a}}$ \\
\hline $\begin{array}{c}\text { Infected }+ \\
\text { curcumin }\end{array}$ & $23 \pm 1.08$ & $24.38 \pm 0.69$ & $27.85 \pm 0.32^{\mathrm{b}}$ & $27.75 \pm 0.92$ & $28.25 \pm 0.63$ & $30.13 \pm 0.66$ & $27.50 \pm 0.96^{\mathrm{b}}$ & $22.50 \pm 1.62$ \\
\hline \multicolumn{7}{|c|}{${ }^{\mathrm{a}}$ significant difference from phosphate buffer group, ${ }^{\mathrm{b}}$ significant difference from infected untreated group. } \\
Table 2. Changes in organ/body ratio of mice after 2 weeks of treatment.
\end{tabular}

Table 2: Changes in organ/body ratio of mice after 2 weeks of treatment.

\begin{tabular}{|c|c|c|c|c|}
\hline Group & Liver weight & Liver/body ratio & Spleen weight & Spleen/body ratio \\
\hline Phosphate buffer & $1.10 \pm 0.08$ & $4.49 \pm 0.23$ & $0.09 \pm 0.01$ & $0.39 \pm 0.01$ \\
\hline Curcumin & $1.31 \pm 0.06$ & $5.24 \pm 0.30$ & $0.11 \pm 0.01$ & $0.42 \pm 0.02$ \\
\hline Infected untreated & $2.28 \pm 0.14$ & $9.83 \pm 0.28^{\mathrm{a}}$ & $0.34 \pm 0.06$ & $1.38 \pm 0.09^{\mathrm{a}}$ \\
\hline Infected + curcumin & $1.85 \pm 0.29$ & $8.27 \pm 0.13^{\mathrm{b}}$ & $0.28 \pm 0.02$ & $1.28 \pm 0.05$ \\
\hline
\end{tabular}

Table 3: Granuloma reduction rate of infected curcumin treated mice.

\begin{tabular}{|c|c|c|}
\hline Variants & Diameter $(\mu \mathrm{m})$ & Number \\
\hline Average & $398.96 \pm 27.84$ & $14.17 \pm 1.66$ \\
\hline Reduction rate & 14.6 & 49.72 \\
\hline $\mathrm{P}$ value & - & 0.000 \\
\hline
\end{tabular}




\section{Discussion}

Growth retardation is one of the main symptoms correlated with schistosomiasis $m a-$ nsoni (Bergquist et al, 2004). This retardation was proved in the present swtudy as the infected-untreated mice showed significant reduction in average of body weight especially in the last experimental week compared with control mice. Curcumin treated mice didn't show great enhancement within the experimental study as compared to the infected untreated mice. The significant changes were recorded only in the third week of infection and the first week of treatment.

In the current study, there were highly significant increases in the liver and the spleen to body ratio of the infected untreated animals when compared with the control mice. Enlargement of the liver resulted from egg deposition in liver and spleen enlargement was due to passive congestion of blood flow and hyperplasia reticuloendothelial tissues (Hamed, 2011; Wilson et al, 2011). Curcuma longa rhizome was proved by Kim et al. (2011) as a drug causing enhancement in liver/body ratio.

Schistosomiasis correlated with some histopathological disorders in the liver including atrophy of liver lobules, damage of hepatic cords, degeneration of cells and finally necrosis due to granuloma, and Kupffer cells hypertrophy and pigmentation. These disorders also include depletion of carbohydrates and raised lipid vacuoles (Mostafa, et al, 2011; Mahmoud et al, 2016).

In the present study, liver sections of infected-untreated mice showed granulomas, dilation of blood sinusoid, damaged hepatocytes, and cellular infiltration. The efficiency of $C$. longa itself to heal the histopathological disorders in the liver tissue was reported (Elhaggagy et al, 2014). In this study, curcumin caused an enhancement degree of the hepatic histopathological disorders. Reduction in granuloma number in the infected group treated with curcumin may be used as an indicator of reduction in egg deposition, as eggs release proteolytic enzymes inducing typical eosinophilic inflammatory and granulomatous reactions, which turn into fibrotic deposits (Cheever et al, 2000).

In infected-untreated mice, spleen sections showed necrotic regions, fibers formation, and no boundary between the white and the red pulps. This agreed with Dakhil et al. (2017). Infected mice treated with curcumin showed enhancement necrotic and fibrotic regions. The therapeutic ability of curcumin in enhancing the architecture of the spleen agreed with Badria et al. (2015).

\section{Conclusion}

The study showed that schistosomiasis caused severe pathological lesions in both liver and spleen tissues of infected untreated mice. But, curcumin enhanced liver/body ratio and hepatomegaly disorder reduced as compared with infected-untreated mice. So, curcumin ameliorated the pathological changes among in infected-treated mice. Curcumin could be a marker to evaluate therapeutic efficiency.

Ethical standards: Ethical considerations were confirmed by the Ethical Committee of Faculty of Science, Port Said University.

Statement of conflict of Interest: The authors neither have a conflict of interest nor received fund.

\section{References}

Anand, P, Thomas, SG, Kunnumakkara, AB, Sundaram, C, Harikumar, KB, Sung, B, et al, 2008: Biological activities of curcumin and its analogues (Congeners) made by man and Mother Nature. Biochem. Pharmacol.76:1590-611.

Araújo, AP, Frezza, TF, Allegretti, SM, Giorgio, S, 2010: Hypoxia, hypoxia-inducible factor$1 \alpha$ and vascular endothelial growth factor in a murine model of Schistosoma mansoni infection. Exp. Mol. Pathol. 89:327-33.

Badria, FA, Ibrahim, AS, Badria, AF, Elmarakby, AA, 2015: Curcumin attenuates iron accumulation and oxidative stress in the liver and spleen of chronic iron-overloaded rats. PLoS. One 10:e134156.

Bergquist, R, Utzinger, J, Chollet, J, ShuHua, X, Weiss, NA, et al, 2004: Triggering of high-level resistance against $S$. mansoni reinfection by artemether in the mouse model. Am. J. Trop. Med. Hyg. 71:774-7. 
Černy, D, Lekić, N, Vaňova, K, Muchova, L, Kmoničkova, E, et al, 2011: Hepatoprotective effect of curcumin in lipopolysaccharide/Dgalactosamine model of liver injury in rats: Relationship to HO-1/CO antioxidant system. Fitorapia. 82:786-91.

Cheever, AW, Hoffmann, KF, Wynn, TA, 2000: Immunopathology of schistosomiasis $m a$ nsoni in mice and men. Immunol. Today 21: 465-6.

Crellen, T, Walker, M, Lamberton, PH, Kabatereine, NB, Tukahebwa, EM, et al, 2016: Reduced efficacy of praziquantel against Schistosoma mansoni is associated with multiple rounds of mass drug administration. Clin. Infect. Dis. 63:1151-9.

Dakhil, MA, Khalil, MF, Diab, MSM, Bauomy, AA, Al-Quraishy, S, 2017: Effect of gold nano-particles on mice splenomegaly induced by schistosomiasis mansoni. Saudi J. Biol. Sci. 24: 1418-23.

Elhaggagy, AA, Alsaggaf, S, Amin, HA, 2014: The preventive and therapeutic role of curcumin in liver cirrhosis. Life Sci. 11:328-38.

Hamed, MA, 2011: Potency of detergents in enhancing Schistosoma mansoni tegumental antigen. J. Infect. Dev. Ctries 5:209-15.

Hotez, PJ, Molyneux, DH, Fenwick, A, Kumaresan, J, Sachs, SE, et al, 2007: Control of neglected tropical diseases. N. Engl. J. Med. 357: 1018-27.

Hussein, A, Rashed, S, El hayawan, I, El-Sayed, R, Ali, H, 2017: Evaluation of the anti-schistosomal effects of turmeric (Curcuma longa) versus praziquantel in Schistosoma mansoni infected mice. Iran. J. Parasitol. 12:587-96.

Jatsa, HB, Feussom, NG, Nkondo, ET, Kenfack, MC, Simo, ND, et al, 2018: Efficacy of $O z-$ oroa pulcherrima Schweinf methanolic extract against Schistosoma mansoni-induced liver injury in mice. J. Tradit. Compl. Med. 9:304-11.

Kim, J, Ha, HL, Moon, HB, Lee, YW, Cho, C K, 2011: Chemopreventive effect of Curcuma longa linn on liver pathology in hbx transgenic mice. Integr. Canc. Ther. 10:168-77.

Mahmoud, AAF, Warren, KS, 1974: Antiinflammatory effect of tartaremetic and niridazole suppression of schistosoma egg granuloma. J. Immunol. 112:222-8.
Mahmoud, EA, ELbessoumy, AA, 2014: Hematological and biochemical effects of curcumin in Schistosoma mansoni infected mice. Assiut. Vet. Med. J. 60:184-94.

Mahmoud, YI, Riad, NH, Taha, H, 2016: Garlic attenuates histological and histochemical alterations in livers of Schistosoma mansoni infected mice. Biotech. Histochem. 91:389-95.

Mostafa, OMS, Eid, RA, Adly, MA, 2011: Antischistosomal activity of ginger (Zingiber officinale) against Schistosoma mansoni harbored in C57 mice. Parasitol. Res. 109:395-403.

Olivier, L, Stirewalt, MA, 1952: An efficient method for exposure of mice to cercariae of $S$. mansoni. J. Parasitol. 38:19-23.

Reis, LF, Ventura, TG, Souza, SO, Arana-Pino, A, Pelajo-Machado, M, et al, 2001: Quantitate and qualitative interferences of pentoxifillyne on hepatic Schistosoma mansoni granulomas: effects on extracellular matrix and eosinophil population. Mem. Inst. Oswaldo Cruz 96: 107-12.

Richter, J, Bode, JG, Blondin, D, Kircheis, G, Kubitz, R, et al, 2015: Severe liver fibrosis caused by Schistosoma mansoni: management and treatment with a transjugular intrahepatic portosystemic shunt. Lanc. Infect. Dis. 15:731-7. Wang, Y, Zhang, J, Yin, J, Shen, Y, Wang, Y, et al, 2015: The formation of egg granulomas in the spleens of mice with late Schistosoma japonicum infection alters splenic morphology. Parasit. Vectors 8:375-9.

WHO, 2018: Available online at http://www. who.int/en/news-room/factsheets/detail/schistosomiasis.

WHO, 2019: Schistosomiasis, fact sheet. Available at http://www.who.int/mediacentre/factshe ets/fs115/en/.

Wilson, S, Vennervald, BJ, Dunne, DW, 2011: Chronic hepatosplenomegaly in African School Children: A common but neglected morbidity associated with schistosomiasis and malaria. PLoS. Negl. Trop. Dis. 5:e1149.

Woldegerima, E, Bayih, AG, Tegegne, Y, Aemero, M, Zeleke, A, 2019: prevalence and reinfection rates of Schistosoma mansoni and praziquantel efficacy against the parasite among primary school children in Sanja Town, Northwest Ethiopia. J Parasitol Res. 2019: e3697216.

\section{Explanation of Figures}

Fig. 1: Liver sections of mice treated with: A-B (phosphate buffer), C-D (curcumin), E-G (infected-untreated), and H-I (Infected + curcumin). HC; hepatocytes, BS; blood sinusoids, KC; Kupffer cells, Black arrowhead; deformations areas, White arrowhead; cellular infiltration, G; granuloma, Black arrow; fibrous portion of granuloma, White arrow; cellular portion of granuloma. 
Fig. 2: Spleen sections of mice treated with: A-B (phosphate buffer), C-D (curcumin), E-G (infected-untreated), and H-I (Infected + curcumin). RP; red pulp, WP; white pulp, CA; central arteriole, Black arrowhead; necrotic areas, White arrowhead; fibrosis.
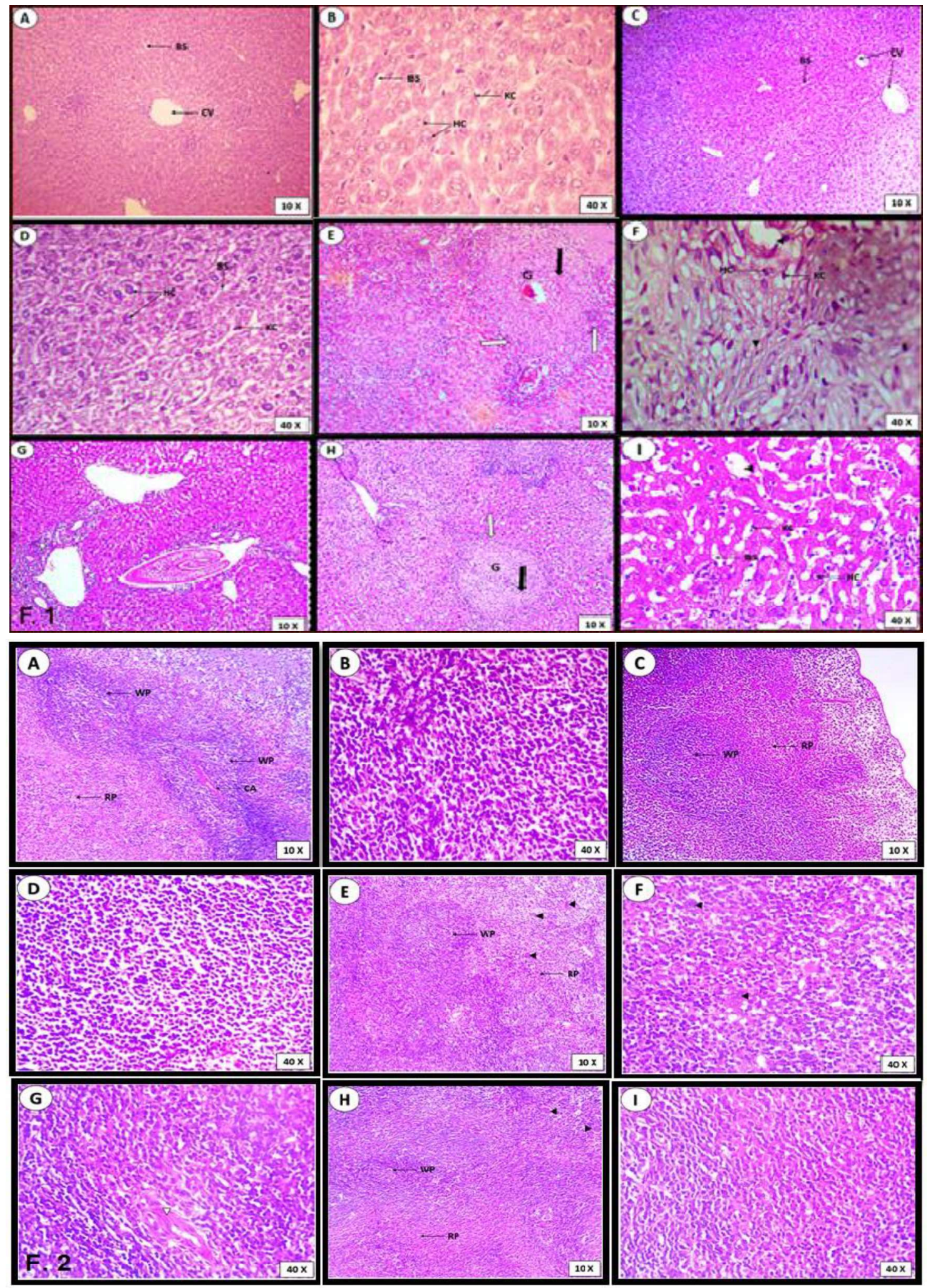